\title{
Comparative ToxicityAssessmentof Aqueous and Ethanolic Bark Extracts of Mahogany: Khaya grandifoliolaon Mangrove Periwinkle; Pachymelania aurita
}

\author{
Okonkwo C. E. ${ }^{1} \quad$ Chukwu L. O. ${ }^{2} \quad$ Igwegbe A. N. ${ }^{1} \quad$ Oke I. A. ${ }^{1} \quad$ Yusuf W. A. ${ }^{1}$ \\ 1.Nigerian Institute for Oceanography and Marine Research, 3 Wilmot Point Street, Victoria Island, Lagos, \\ Nigeria \\ 2.Department of Marine Sciences, University of Lagos, Nigeria
}

\begin{abstract}
The acute toxicities of extracts of Bark of Mahogany (Khaya grandifoliola) in aqueous and ethanolic solutions were evaluated against the edible periwinkle (Pachymelania aurita) in laboratory bioassays. From the derived toxicity indices, the aqueous extract $\left(96 \mathrm{~h} \mathrm{LC}_{50}=17.4 \mathrm{ml} / \mathrm{L}, 3.48 \mathrm{~g} / \mathrm{L}\right)$ was found to be 24.2 times less toxic than the ethanolic extracts $\left(96 \mathrm{~h} \mathrm{LC} \mathrm{LC}_{50}=0.24 \mathrm{ml} / \mathrm{L}, 0.144 \mathrm{~g} / \mathrm{L}\right)$. ANOVA showed significant differences in the response of Pachymelania aurita to different concentrations of exposure to extracts at $48 \mathrm{hr}, 72 \mathrm{hr}$ and $96 \mathrm{hr}$ respectively. Symptoms of toxicosis observed in the test organisms were immobility and eventually death.
\end{abstract}

Keywords: Toxicity, Pachymelania aurita, Khaya grandifoliola, Edible periwinkle, Lagos lagoon.

DOI: $10.7176 / \mathrm{JBAH} / 10-7-02$

Publication date: April $30^{\text {th }} 2020$

\section{INTRODUCTION}

In Nigeria, the lagoons and estuaries have continued to be under intensifying pressure from pollution, which is perhaps, the most serious threat that can be posed to the Nigerian coastal waters. Water pollution threatens aquatic life in freshwater bodies, transition zones as well as marine habitats. The most notable pollution point sources arise from the dumping of untreated or partially treated sewage in the lagoon (Andemet al., 2013, Ekundayo, 1977; Akpata and Ekundayo, 1978; Chukwu, 2002); deposition of DDT, dyes and heavy metals from industrial effluents (Ajao, 1989, Ajao and Fagade, 1990 and Chukwu, 2006); erosion of coastal beaches (Ibe, 1988); leachates from solid waste dumps (Fodeke, 1985); discharge of biodegradable wood waste from sawmills located along the lagoon (Nwankwo and Akinsoji, 1989; Nwankwo et al., 1994; Chukwu and Okeowo, 2006).

The appreciation for wooden products hasn't wavered over the years and as such these manufacturing operations generate wood residue which could form leachate in contact with water (such as bark, sawdust, shavings, wood chops and off-cuts). Wood residue decomposition is a slow process that can result in decades of leachate production. During the period of prolonged water saturation, substances found naturally in wood such as resin acids, lignin, legumes, fatty acids and tannins dissolve from the wood waste in high concentrations and can have impacts on the ground water, nearby surface water as well as aquatic bodies.

Benthic organisms, most of which are highly immobile, are effective in pollution studies since they are easy to monitor and often lack the ability to escape from polluted sites (Nkwojiet al., 2010).By being filter feeders are most likely to filter the water of these pollutants. Over a period, these toxins may accumulate in the tissues of these organisms, disrupt their body functions, alter their growth and reproductive patterns or eventually lead to their death (Chukwu and Odunzeh, 2003).

The edible periwinkle Pachymelania aurita was chosen for this study due to its ability to tolerate high levels of pollution and major structural changes Brown and Ajao (2004). This study aims to determine the relative toxicity $\left(\mathrm{LC}_{50}\right)$ of ethanolic and aqueousbark extracts of Mahogany Khaya grandifoliola on P. aurita.

\section{MATERIALS AND METHODS}

Test Animals: Pachymelania aurita was handpicked from the coastal waters in the shelly sand sediments of the southern part of the Lagos lagoon bordering the University of Lagos during low tides.100 organisms were kept for 14 days in plastic tanks $(755 \mathrm{~cm}$ by $30 \mathrm{~cm}$ by $32 \mathrm{~cm})$ containing lagoon water (aerated) and sediments from the site of collection of the animals to stimulate a typical brackish water medium.

\section{Test Compounds}

Aqueous Extracts: 200g of ground bark of Khaya grandifoliola was sieved, soaked in 1L of distilled water for $72 \mathrm{hrs}$, filtered through a muslin cloth and stored in a plastic container at room temperature.

Ethanolic Extracts: $1500 \mathrm{~g}$ of ground $K$. grandifoliola was put in a Soxhlet extractor with $2.5 \mathrm{~L}$ of $98 \%$ absolute ethanol reagent. It was heated for $3-4$ hrs. The solvent was collected and stored in a silver flask. The ethanol was recovered by distillation and the residue collected into a $100 \mathrm{ml}$ beaker and was concentrated by heating in a hot air oven at $78^{\circ} \mathrm{C}$. it was cooled in a condenser, weighed and stored in a dark glass bottle. 
Determination of physico-chemical parameters of test media:

In the course of this assessment, water $\mathrm{pH}$, total dissolved solids (TDS), dissolved oxygen and salinity were measured as part of the standard process of operation.

\section{Bioassay procedures}

Preparation of Substrate:The shelly sand substrates obtained wet from the lagoon were dried in the sun to standardize moisture content and particle size. The prepared sediment was then spread out in the test medium (250g for acute tests and $1500 \mathrm{~g}$ for sub-lethal tests).

Preliminary and Definite tests:The acute single toxicity procedure followed methods used for fixed - point discharge and static renewal bioassays which involved the determination of the lethal concentration of the aqueous and ethanolic extracts of bark of $K$. grandifoliola that would cause the mortality of $50 \%$ of the exposed organisms within 24, 48, 72 and $96 \mathrm{hr}$ respectively.

Preliminary tests were performed to determine the suitable concentration range of effluents for the experiment. $1000 \mathrm{ml}$ of the dilution water (from the Lagos lagoon: the site of organism collection) was introduced into the glass tanks. Different concentrations of the toxicants were also introduced into the glass tanks per litre of the lagoon water. Ten active organisms were selected from the acclimatized tanks and transferred into the bioassay tanks. The control tank was kept free of any form of toxicant.

A definitive test was performed using 6 different concentrations of the extracts. Each test was done in triplicates. The mean value of the results was taken as percentage mortality to eliminate errors due to handling differences in size and weight and other intrinsic physiological imbalances in the organism. The grade of concentration used were:

Aqueous extract: 0ml/L (control); 10ml/L (2g/L); 40ml/L (8g/L);60ml/L (12g/L); 80ml/L (16g/L) and $100 \mathrm{ml} / \mathrm{L}(20 \mathrm{~g} / \mathrm{L})$

Ethanolic extract: $0 \mathrm{ml} / \mathrm{L}$ (control); $0.2 \mathrm{ml} / \mathrm{L}(0.12 \mathrm{~g} / \mathrm{L}) ; 0.4 \mathrm{ml} / \mathrm{L}(0.24 \mathrm{~g} / \mathrm{L}) ; 0.6 \mathrm{ml} / \mathrm{L}(0.36 \mathrm{~g} / \mathrm{L}) ; 0.8 \mathrm{ml} / \mathrm{L}$ $(0.48 \mathrm{~g} / \mathrm{L})$ and $1.0 \mathrm{ml} / \mathrm{L}(0.60 \mathrm{~g} / \mathrm{L})$.

\section{Assessment of Quantal Response}

Immobility was the quantal response assessed in this study. Mortality count was taken once every $24 \mathrm{hrs}$ over a $96 \mathrm{hr}$ period. $P$. aurita were considered dead when there was no mobility response to gentle prodding with a pin and this was further confirmed with a change in odour from its original sea weedy smell to a pungent odour. Symptoms of extract toxicity and behavioral changes such as disorientation and inactivity were monitored on a 12-hourly basis for a $96 \mathrm{hr}$ duration. No immobility was recorded in the control tank.

Statistical Analysis: dose immobility (toxicological data) was analyzed by probit analysis after Finney (1971). Indices of toxicity were based on $\mathrm{LC}_{5}, \mathrm{LC}_{50}, \mathrm{LC}_{95}$ and T.F values. The lethal concentration that will cause $50 \%$ immobility of the exposed population was taken as the median tolerance limit, $\mathrm{LC}_{50}$, while $\mathrm{LC}_{95}$ as the lethal concentration that would cause $95 \%$ immobility. T.F is the toxicity factor of relative potency measurements. These values are used as indices for assessing the susceptibility of the test organisms to the toxicants and were determined using methods according to Reish and Oshida (1986). One-way analysis of variance (ANOVA) and comparison of Student Newman Keuls (SNK) tests were used to test for statistical differences in the results of 96hrs toxicity tests according to Chukwu (2001). All analysis was performed using computer statistical package SPSS 10.0.

\section{RESULTS AND DISCUSSION}

Physico-Chemical parameters of the test media: the mean values obtained for the physico-chemical parameters of the test media through out the period of the experiment were as follows;

Table 1: Analysis of the Physico-Chemical parameters of test media

\begin{tabular}{|l|c|}
\hline \multicolumn{1}{|c|}{ Parameters } & Results \\
\hline $\mathrm{pH}$ & 8.1 \\
\hline Total Dissolved Solids & 3.48 \\
\hline Dissolved Oxygen & $8.40 \mathrm{mgl} / \mathrm{L}$ \\
\hline Salinity & $20 \%$ o \\
\hline Temperature & $25.5^{\circ} \mathrm{C}$ \\
\hline
\end{tabular}


Relative toxicities of aqueous and ethanolic extracts of Khaya grandifoliola against Pachymelania aurita:

Table 2: relative toxicity of aqueous extract of $K$. grandifoliola against $P$. aurita

\begin{tabular}{|c|c|c|c|c|c|c|c|}
\hline $\begin{array}{l}\text { Exposure } \\
\text { time }\end{array}$ & $\begin{array}{l}\text { LC50 (95\% } \\
\text { C.L.ml/L) }\end{array}$ & $\begin{array}{l}\text { LC95 } \\
(95 \% \text { C.L.ml/L) }\end{array}$ & $\begin{array}{l}\mathrm{LC} 5 \\
(95 \% \text { C.L.ml/L) }\end{array}$ & $\begin{array}{l}\text { Slope } \\
\pm \\
\text { S.E }\end{array}$ & D.F & $\begin{array}{l}\text { Probitline } \\
\text { equation }\end{array}$ & T.F \\
\hline 48 & $\begin{array}{l}95.65(63.53- \\
915.08)\end{array}$ & $\begin{array}{l}9460.10(957.30- \\
344.80)\end{array}$ & $0.97(0.00-5.42)$ & $0.82 \pm 0.31$ & 3 & $Y=3.37+0.82 x$ & 1 \\
\hline 72 & $\begin{array}{l}31.31(19.03- \\
43.94)\end{array}$ & $\begin{array}{l}432.29 \quad(207.16- \\
2472.38)\end{array}$ & $2.27(0.24-5.79)$ & $1.44 \pm 0.31$ & 3 & $Y=2.84+1.44 x$ & 3.05 \\
\hline 96 & $\begin{array}{l}17.41 \\
25.93)\end{array}$ & $\begin{array}{l}235.50 \quad(128.05- \\
944.65)\end{array}$ & $1.29(0.10-3.73)$ & $1.45 \pm 0.31$ & 3 & $Y=3.20+1.45 x$ & 5.49 \\
\hline
\end{tabular}

C.L $=$ confidence limit

L.C $=$ lethal concentration

D.F $=$ degree of freedom

T.F $=$ toxicity factor

$\mathrm{T} . \mathrm{F}=\frac{L C_{50} \text { of test compound at } 48 \mathrm{hrs}}{L C_{50} \text { of testcompound at other hours }(72 \text { and } 96 \mathrm{hrs})}$

Table 3: relative toxicity of ethanolic extract of $K$. grandifoliola against $P$. aurita

\begin{tabular}{|c|c|c|c|c|c|c|c|}
\hline $\begin{array}{l}\text { Exposure } \\
\text { time }\end{array}$ & $\begin{array}{l}C_{5}(95 \% \\
\text { C.L.ml/L) }\end{array}$ & $\begin{array}{l}\mathrm{LC}_{50} \\
(95 \% \\
\text { C.L.ml/L) }\end{array}$ & $\begin{array}{l}\mathrm{LC} 95 \\
(95 \% \\
\text { C.L.ml/L) }\end{array}$ & $\begin{array}{l}\text { Slope } \\
\pm \text { S.E }\end{array}$ & D.F & $\begin{array}{l}\text { Probit line } \\
\text { equation }\end{array}$ & T.F \\
\hline 48 & $\begin{array}{ll}0.06 & (0.00- \\
0.10) & \end{array}$ & $\begin{array}{l}0.98(0.68- \\
3.19)\end{array}$ & $\begin{array}{l}15.06 \quad(4.02- \\
5910.03)\end{array}$ & $1.39 \pm 0.45$ & 3 & $Y=5.01+1.39 x$ & 1 \\
\hline 72 & $\begin{array}{ll}0.06 & (0.01- \\
0.12) & \end{array}$ & $\begin{array}{ll}0.43 & (0.31- \\
0.55) & \\
\end{array}$ & $\begin{array}{l}2.29 \\
12.63)\end{array}$ & $1.96 \pm 0.45$ & 3 & $Y=5.72+1.96 x$ & 2.27 \\
\hline 96 & $\begin{array}{ll}0.04 & (0.01- \\
0.09) & \\
\end{array}$ & $\begin{array}{ll}0.24 & (0.13- \\
0.32) & \\
\end{array}$ & $\begin{array}{ll}1.47 & (0.97- \\
3.83) & \\
\end{array}$ & $2.10 \pm 0.47$ & 3 & $Y=6.30+2.10 x$ & 4.06 \\
\hline
\end{tabular}

C.L $=$ confidence limit $\quad$ L.C $=$ lethal concentration

D.F $=$ degree of freedom $\quad$ T.F $=$ toxicity factor

$\mathrm{T} . \mathrm{F}=\frac{L C_{50} \text { of test compound at } 48 \mathrm{hrs}}{L C_{50} \text { of testcompound at other hours }(72 \text { and } 96 \mathrm{hrs})}$

The result of the dose mortality of aqueous and ethanolic extracts againt $P$. aurita at 48,72 and $96 \mathrm{hr}$ periods of exposure are shown in the tables 2 and 3. The median lethal concentration of aqueous extract against $P$. aurita decreased as the duration of exposure increased. Fig. 1 shows the graph of probit response and log-dose concentration of aqueous extract against $P$. aurita. From table 3, the concentrations of ethanolic extract that will cause $50 \%$ immobility to table 3 , the concentrations of ethanolic extract that will cause $50 \%$ immobility to $P$. aurita $\left(\mathrm{LC}_{50}\right)$ at 48,72 and $96 \mathrm{hr}$ periods of exposure were $0.95 \mathrm{ml} / \mathrm{L}, 0.43 \mathrm{ml} / \mathrm{L}$ and $0.24 \mathrm{ml} / \mathrm{L}$ respectively. Fig 2 shows the graph of probit response and log-dose of ethanolic extract.

Based on the computed toxicity factor $\left(96 \mathrm{~h} \mathrm{LC}_{50}\right)$ ratios, the ethanolic extract was found to be 7.5 times more toxic than aqueous extract against $P$. aurita (table 2 and 3 ).

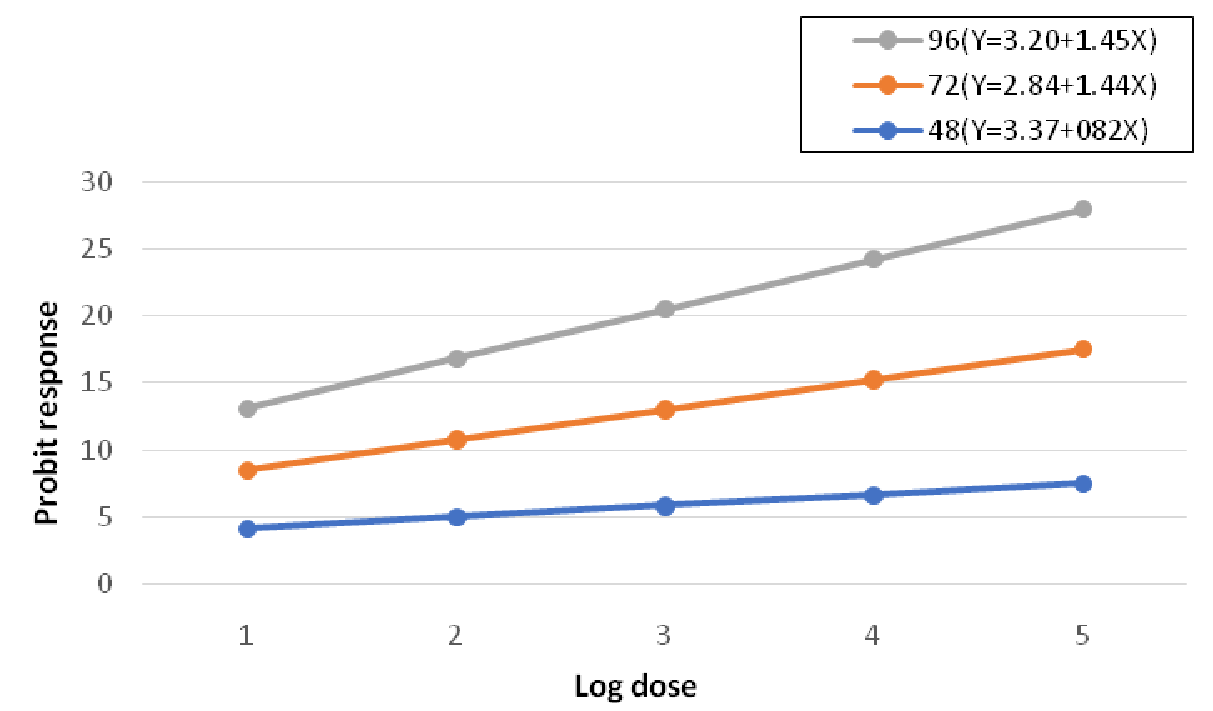

Fig. 1: Probit response log-dose of aqueous extract of Khaya grandifoliola against Pachymelania aurita 


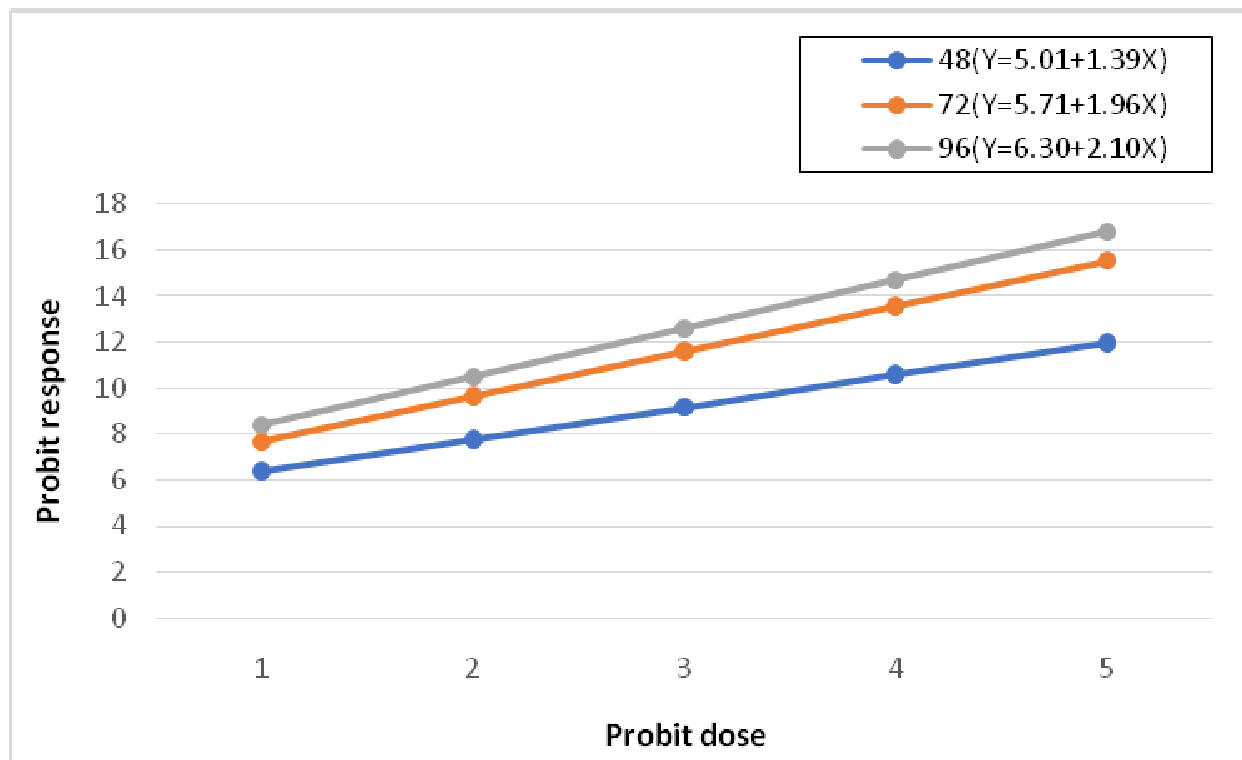

Fig. 1: Probit response log-dose of ethanolic extract of Khaya grandifoliola against Pachymelania aurita

The randomized ANOVA showed significant differences between all the treatment at 48, 72, and 96hr of exposure to the extracts.

SNK tests at $5 \%$ significant level, the immobility response at $10 \mathrm{ml} / \mathrm{L}, 40 \mathrm{ml} / \mathrm{L}, 60 \mathrm{ml} / \mathrm{L}, 80 \mathrm{ml} / \mathrm{L}$ and $100 \mathrm{ml} / \mathrm{L}$ were significantly different from the control at 48, 72 and $96 \mathrm{hrs}$ of exposure to aqueous extracts (table 4). However, there was no significant difference between each concentration at 48, 72 and $96 \mathrm{hrs}$ of exposure.

Table 4: percentage mean immobility response of $\boldsymbol{P}$. aurita exposed to different concentration of aqueous extract of $K$. grandifoliola.

\begin{tabular}{|l|c|c|c|c|c|}
\hline Conc. (mI/L) & \multirow{2}{*}{ No of org. } & \multicolumn{3}{|l|}{ Percentage mortality (\%) / Time (hrs) } \\
\cline { 3 - 6 } & & 24 & 48 & 72 & 96 \\
\hline Control & 30 & - & $0^{\mathrm{a}}$ & $0^{\mathrm{a}}$ & $0^{\mathrm{a}}$ \\
\hline 10 & 30 & - & $23.3^{\mathrm{b}}$ & $30.0^{\mathrm{b}}$ & $43.3^{\mathrm{b}}$ \\
\hline 40 & 30 & - & $33.3^{\mathrm{c}}$ & $43.3^{\mathrm{c}}$ & $56.7^{\mathrm{c}}$ \\
\hline 60 & 30 & - & $40.0^{\mathrm{cd}}$ & $56.7^{\mathrm{d}}$ & $70.0^{\mathrm{d}}$ \\
\hline 80 & 30 & - & $46.7^{\mathrm{d}}$ & $76.7^{\mathrm{e}}$ & $86.7^{\mathrm{e}}$ \\
\hline 100 & 30 & - & $56.7^{\mathrm{e}}$ & $86.7^{\mathrm{f}}$ & $96.7^{\mathrm{f}}$ \\
\hline
\end{tabular}

Means followed by the same subscript letter in a column are not sig. diff. in the SNK test $(\mathrm{P}=0.05)$

Table 5: percentage mean immobility response of $P$. aurita exposed to different concentration of ethanolic extract of $K$. grandifoliola.

\begin{tabular}{|l|c|c|c|c|c|}
\hline Conc. $(\mathrm{ml} / \mathbf{L})$ & \multirow{2}{*}{ No of org. } & \multicolumn{3}{|c|}{ Percentage mortality (\%) / Time (hrs) } \\
\cline { 3 - 6 } & & 24 & 48 & 72 & 96 \\
\hline Control & 30 & - & $0^{\mathrm{a}}$ & $0^{\mathrm{a}}$ & $0^{\mathrm{a}}$ \\
\hline 0.2 & 30 & - & $20.0^{\mathrm{b}}$ & $26.7^{\mathrm{b}}$ & $46.7^{\mathrm{b}}$ \\
\hline 0.4 & 30 & - & $26.7^{\mathrm{bc}}$ & $46.7^{\mathrm{c}}$ & $63.3^{\mathrm{c}}$ \\
\hline 0.6 & 30 & - & $33.3^{\mathrm{c}}$ & $60.0^{\mathrm{d}}$ & $76.7^{\mathrm{d}}$ \\
\hline 0.8 & 30 & - & $43.3^{\mathrm{d}}$ & $66.7^{\mathrm{d}}$ & $86.7^{\mathrm{e}}$ \\
\hline 1.0 & 30 & - & $56.7^{\mathrm{e}}$ & $80.0^{\mathrm{e}}$ & $93.3^{\mathrm{f}}$ \\
\hline
\end{tabular}

Means followed by the same subscript letter in a column are not sig. diff. in the SNK test $(\mathrm{P}=0.05)$

Similarly, SNK tests at 5\% significant level, the immobility response to ethanolic extracts at $0.2 \mathrm{ml} / \mathrm{L}, 0.4 \mathrm{ml} / \mathrm{L}$, $0.6 \mathrm{ml} / \mathrm{L}, 0.8 \mathrm{ml} / \mathrm{L}$ and $1.0 \mathrm{ml} / \mathrm{L}$ were significantly different from the control at 48,72 and $96 \mathrm{hrs}$ of exposure (table 5). However, at $96 \mathrm{hrs}$ of exposure, there was no significant difference between $1.0 \mathrm{ml} / \mathrm{L}$ and $0.8 \mathrm{ml} / \mathrm{L}$ mean mortality response as shown in table 5.

The summary of the statistical difference between all concentrations pairing at 48, 72 and 96hrs of exposure using SNK is shown in tables 4 and 5.

\section{CONCLUSION}

In this study, there was a record of 50\% immobility when Pachymelania aurita was exposed to $95.65 \mathrm{ml} / \mathrm{L}$, $31.31 \mathrm{ml} / \mathrm{L}$ and $17.41 \mathrm{ml} / \mathrm{L}$ of aqueous extract at 48,72 and $96 \mathrm{hrs}$ of exposure. On the other hand, there was also 
$50 \%$ immobility when exposed to $0.98 \mathrm{ml} / \mathrm{L}, 0.43 \mathrm{ml} / \mathrm{L}$ and $0.24 \mathrm{ml} / \mathrm{L}$ of ethanolic extract. The toxicity of both extracts increased with time, that is, $96 \mathrm{hr} \mathrm{LC}_{50}$ value for periwinkles in aqueous extracts was 5.49 times greater than $24 \mathrm{hr} \mathrm{LC} \mathrm{LC}_{50}$ as the $\mathrm{LC}_{50}$ values decreased from $95.65 \mathrm{ml} / \mathrm{L}$ to $17.41 \mathrm{ml} / \mathrm{L}$.Furthermore, the ethanolic extract was found to be 24.2 times more toxic than the aqueous extract which agrees with works done by Chukwu and Okeowo(2006).

The toxicity increased between 24 and 96 hours as $\mathrm{LC}_{50}$ values decreased, therefore, the longer the period of exposure of an organism to a given toxicant, the lower the quantity required to reach tolerance levels.

\section{REFERENCES}

Andem, B. A., Okorafor, K. A.,Eyo, V. O. andEkpo, P. B. (2013). Ecological Impact Assessment and Limnological Characterization in the Intertidal Region of Calabar River Using Benthic Macroinvertebrates as Bioindicator Organisms. International Journal of Fisheries and Aquatic Studies. 1(2):8-14.

Ajao, E. A. (1989). The influence of domestic and industrial effluents on populations of sessile and benthic organisms in Lagos lagoon. Ph.D. Thesis, University of Ibadan, Nigeria. $411 \mathrm{pp}$.

Ajao, E. A. and Fagade, S. O. (1990). Production and population dynamics of Pachymelania aurita mallus. Archir for Hydrobiologie. 120(1): 97-107.

Akpata, T. V. I. and Ekundayo, J. A. (1978). Faecal pollution of the Lagos Lagoon. Nigerian Journal of Science. 12: $39-53$.

Brown, C. A. and Ajao, E. A. (2004). Effects of topographical modifications on the composition and abundance of macro fauna on southern Lagos lagoon (Ikoyi). West African Journal of Applied Ecology.5: 41-50.

Chukwu, L. O. (2002). Histophysiological indices of osmotic stress in the euryhaline teleost Elopslacerta(Val) adapted to different salinity regimes. Journal of Science Technology and Environment. 2(2): 1-7.

Chukwu, L. O. (2002). Physico-chemical characterization of pollutant load of treated industrial effluents in Lagos metropolis. Journal of Industrial Pollution Control. 22(1): 147-153.

Chukwu, L. O. and Odunzeh, C. C. (2003). Toxic and Sublethal effects of spent lubricant oil on the gill morphology of the tropical teleost Oreochromis niloticus(L) Journal of Nigerian Environmental Society. 1 (3): 334-339.

Chukwu, L. O. and Okeowo, O. H. (2006). Piscicidal properties of aqueous and ethanolic back extracts of floating timber logs in a tropical open lagoon. Ecology, Environment and Conservation. 12(1): 37-41.

Ekundayo, J. A. (1977). Environmental consequences of the pollution of the Lagos lagoon. Bulletin of the Science Association of Nigeria. 3: 290-299.

Fodeke, V. A. (1985). Ground water contamination by waste leachates. Ph.D. Thesis, University of Benin, Nigeria. 300pp.

Ibe, A. C. (1988). Coastline Erosion in Nigeria. Ibadan University Press, Ibadan, Nigeria. 217pp.

Nwankwo, D. I. and Akinsoji, A. (1989). The benthic algal community of a sawdust decomposition site in Lagos lagoon. International Journal of Ecology and Environmental Sciences. 15: 197-204.

Nwankwo, D. I., Olugbenga, A. A. and Abdulrasaq, Y. (1994). Floating timber logs as a substrate for periphyton algae in the Lagos lagoon, Nigeria. Pol. Arch. Hydrobiol. 41(4): 419-430.

Nkwoji, J. A., Yakub A., Ajani, G. E., Balogun, K. J., Renner, K.O., Igbo, J. K., Ariyo, A. A., Bello, B. O. (2010).Seasonal Variations in the Water Chemistry and Benthic Macroinvertebrates of a South Western Lagoon, Lagos, Nigeria. Journal of American Science.6(3).

Reish, D. I. and Oshida, H. I. (1986). Manual of Methods of Aquatic Environment Research part 10, Short term state Bioassay. FAO Fish. Tech Paper. 150: 76pp. 